\title{
Serotonin and Mental Disorders: A Concise Review on Molecular Neuroimaging Evidence
}

\author{
Shih-Hsien Lin ${ }^{1,2}$, Lan-Ting Lee, Yen Kuang Yang ${ }^{1,2}$ \\ 'Department of Psychiatry, National Cheng Kung University Hospital, College of Medicine, National Cheng Kung University, ${ }^{2}$ Addiction \\ Research Center, National Cheng Kung University, Tainan, Taiwan
}

\begin{abstract}
Serotonin is one of the most important neurotransmitters influencing mental health and, thus, is a potential target for pharmacological treatments. Functional neuroimaging techniques, such as positron-emission tomography (PET) and single photon emission computed tomography (SPECT), could provide persuasive evidence for the association between mental disorders and serotonin. In this concise review, we focus on evidence of the links between serotonin and major depressive disorders, as well as other mood disorders, anxiety disorders, schizophrenia, addiction, attention deficit hyperactivity disorder (ADHD), and autism.
\end{abstract}

KEY WORDS: Serotonin; Mental disorders; Positron-emission tomography; Single photon emission computed tomography.

\section{INTRODUCTION}

Serotonin is one of the most important neurotransmitters influencing mental health. ${ }^{1)}$ Most serotonin is distributed outside of the central nervous system (CNS), and influences a wide range of physiologic processes in many organs. ${ }^{2)}$ However, the $2 \%$ of serotonin that is present in the CNS plays a pivotal role in the etiology of many mental disorders. Both receptors and transporters play important roles in synapses. 5-Hydroxytryptamine (5-HT) receptors are activated by the serotonin neurotransmitter, while the 5-HT transporter reuptakes the serotonin neurotransmitter from the synaptic cleft. Altered receptor and/or serotonin transporter (SERT) function may be associated with mental disorders.

The development of selective serotonin reuptake inhibitors (SSRIs) illustrates the importance of the serotonergic system with regard to the treatment of mental disorders. Further, the discovery of the role that the serotonin-transporter-linked polymorphic region (5-HTTLPR) plays in the association between stress and mental health highlights the pervasive influence of the serotonin transporter gene. Meanwhile, noninvasive neuroimaging tech-

\footnotetext{
Received: April 15, 2014 / Revised: June 26, 2014

Accepted: August 21, 2014

Address for correspondence: Lan-Ting Lee, MD

Department of Psychiatry, National Cheng Kung University Hospital,

138 Sheng Li Road, North Dist., Tainan 70403, Taiwan

Tel: +886-6-2353535 ext.4200, Fax: +886-6-2759259

E-mail: bce2369@hotmail.com
}

niques, such as positron-emission tomography (PET) and single photon emission computed tomography (SPECT), can be used to study regional receptor and transporter concentrations in specific brain areas. These are important tools that can be used to acquire in vivo brain images and quantitative measurements with regard to the activities of the serotonergic system. ${ }^{3,4)}$

Although there are many families of 5-HT receptors, most studies rely on radioligands for $5-\mathrm{HT}_{1 \mathrm{~A}}$ and $5-\mathrm{HT}_{2 \mathrm{~A}}$. Some of the important radioligands used to study the serotonergic system are shown in Table 1. For instance, $\left[{ }^{11} \mathrm{C}\right]$ WAY-100635 may be the most important radioligand

Table 1. Important PET and SPECT radioligands for serotonergic targets $\left(5-H T_{1 A}, 5-H_{2 A}\right.$, and SERT) in humans

\begin{tabular}{ll}
\hline Target & \multicolumn{1}{c}{ Radioligand } \\
\hline $5-\mathrm{HT}_{1 \mathrm{~A}}$ & $\left({ }^{11} \mathrm{C}\right)$ WAY-100635 \\
$5-\mathrm{HT}_{2 \mathrm{~A}}$ & $\left({ }^{123}\right)-5-$ - -R91150 \\
& $\left({ }^{18} \mathrm{~F}\right)$ setoperone \\
& $\left({ }^{18} \mathrm{~F}\right)$ altanserin \\
& $\left({ }^{18} \mathrm{~F}\right)$ deuteroaltanserin \\
& $\left({ }^{11} \mathrm{C}\right)$ MDL 100907 \\
& Beta- $\left({ }^{123}\right) \mathrm{CIT}$ \\
SERT & $\left({ }^{123}\right)$ ADAM \\
& $\left({ }^{11} \mathrm{C}\right) \mathrm{DASB}$ \\
& $\left({ }^{11} \mathrm{C}\right) \mathrm{MADAM}$ \\
& $\left({ }^{11} \mathrm{C}\right) \mathrm{MCN} 5652$ \\
\hline
\end{tabular}

PET, positron-emission tomography; SPECT, single photon emission computed tomography; 5-HT, 5-hydroxytryptamine; SERT, serotonin transporter.

Source: Paterson et al. $^{3)}$

(a) This is an Open-Access article distributed under the terms of the Creative Commons Attribution Non-Commercial License (http://creativecommons.org/licenses/by-nc/3.0) which permits unrestricted non-commercial use, distribution, and reproduction in any medium, provided the original work is properly cited. 
for $5-\mathrm{HT}_{1 \mathrm{~A}}$; however, there are also other available radioligands. Several radioligands were also developed for 5-HT $2 \mathrm{~A}$. For SERT, Beta- $\left[{ }^{123} \mathrm{I}\right] \mathrm{CIT}$ is one of the most useful radioligands for the SPECT. However, this radiotracer binds both on SERT and dopamine transporter (DAT). Another important radiotracer for SEPCT is $\left[{ }^{123} \mathrm{I}\right] \mathrm{ADAM}$, which selectively binding on SERT only. $\left[{ }^{11} \mathrm{C}\right] \mathrm{DASB}$ and $\left[{ }^{11} \mathrm{C}\right] \mathrm{MADAM}$ are important radioligands for PET. Evidence from neuroimaging studies may enhance our understanding of the role of serotonin in many mental disorders, and the aim of this essay was thus to provide a concise and updated review of the literature on this topic.

\section{MAIN SUBJECTS}

\section{Major Depressive Disorder (MDD)}

MDD is one of the most important mental disorders associated with altered serotonergic activity, and several extensive reviews of the literature exist on this topic. ${ }^{5)}$ Drevets et al. ${ }^{6}$ used PET in conjunction with $\left[{ }^{11} \mathrm{C}\right]$ WAY-100635, and found that the binding potential of $5-\mathrm{HT}_{1 \mathrm{~A}}$ receptors in the raphe and mesiotemporal cortex of unmedicated subjects with MDD was lower than that in controls. Similar results were found among medicated and unmedicated MDD subjects in other studies, ${ }^{7,8)}$ as well as among patients with recurrent MDD. ${ }^{9}$ However, not all studies agree on this issue. For example, in another PET study that used the same radioligand, MDD patients using antidepressants had greater $5-\mathrm{HT}_{1 \mathrm{~A}}$ receptor binding potential in the raphe and mesiotemporal cortex than controls and antidepressant-naïve patients with MDD; however, receptor binding potential was not significantly different between drug-naïve MDD patients and controls. ${ }^{10)}$ All of these earlier studies indicate that serotonin receptors are associated with MDD. The role of serotonin transporters, which influence the level of serotonergic activity, has also been examined in related neuroimaging studies. While it was demonstrated that a lower level of SERT availability in the midbrain is related to MDD, ${ }^{11-13)}$ several studies presented findings that contradicted this. ${ }^{14-16)}$ No differences were found in SERT availability between drug-free euthymic patients with MDD and controls. ${ }^{17)}$ However, our previous study demonstrated that SERT availability in the midbrain was significantly lower in subjects with a first-degree family history of MDD than in healthy subjects. ${ }^{18)}$ Meanwhile, $\left[{ }^{11} \mathrm{C}\right] \mathrm{McN}$ 5652 studies indicated a lower SERT availability binding

Table 2. The summary of the findings on major depressive disorder (MDD)

\begin{tabular}{|c|c|c|c|c|c|}
\hline Authors (year) & Target & Radioligand & Subject & Regions & Finding \\
\hline Drevets et al. (1999) & $5-\mathrm{HT}_{1 \mathrm{~A}}$ & $\left({ }^{11} \mathrm{C}\right) W A Y-100635$ & Unmedicated & RN, mesiotemporal cortex & MDD $<$ controls \\
\hline Sargent et al. (2000) & $5-\mathrm{HT}_{1 \mathrm{~A}}$ & ( ${ }^{11}$ C)WAY- 100635 & $\begin{array}{l}\text { Unmedicated and } \\
\text { medicated }\end{array}$ & $\begin{array}{l}\text { Frontal, temporal, and limbic } \\
\text { cortex }\end{array}$ & $\begin{array}{l}\text { MDD (medicated and } \\
\text { unmedicated) }<\text { controls }\end{array}$ \\
\hline Hirvonen et al. (2008) & $5-\mathrm{HT}_{1 \mathrm{~A}}$ & $\left({ }^{11}\right.$ C)WAY-100635 & Unmedicated & $\begin{array}{l}\text { AC, AMY, ANG, DLP, ITG, } \\
\text { MTG, STG, HIP, INS, MFC, } \\
\text { ORB, PC, dorsal RN, SG, VLP }\end{array}$ & MDD $<$ controls \\
\hline Parsey et al. (2006) & $5-\mathrm{HT}_{1 \mathrm{~A}}$ & $\left({ }^{11}\right.$ C)WAY- 100635 & Unmedicated & $\begin{array}{l}\text { RN, VPFC, MPFC, MPFC, DLP, } \\
\text { AC, CIN, AMY, HIP, PHG, INS, } \\
\text { TEM, PAR, OCC }\end{array}$ & No significant difference \\
\hline Bhagwagar et al. (2004) & $5-\mathrm{HT}_{2 \mathrm{~A}}$ & $\left({ }^{11}\right.$ C)WAY-100636 & $\begin{array}{l}\text { Recurrent MDD (recovered } \\
\text { and antidepressant free) }\end{array}$ & $\begin{array}{l}\text { Temporal, parietal, prefrontal } \\
\text { and cingulate cortex }\end{array}$ & MDD $<$ controls \\
\hline Malison et al. (1998) & SERT & Beta- $\left.-{ }^{123} \mid\right) C l T$ & Drug-free MDD & Brainstem & MDD $<$ controls \\
\hline Newberg et al. (2005) & SERT & Beta- $\left({ }^{123}\right) \mathrm{ClT}$ & Drug-free MDD & Midbrain & MDD $<$ controls \\
\hline Joensuu et al. (2007) & SERT & $\left({ }^{123} \mathrm{l}\right)$ nor- $\beta$-ClT & Unmedicated & Midbrain & MDD $<$ controls \\
\hline Ahonen et al. (2004) & SERT & $\left({ }^{123}\right)$ ADAM & Drug-free MDD & Midbrain & No significant difference \\
\hline Catafau et al. (2006) & SERT & $\left({ }^{123}\right.$ I)ADAM & Drug-free MDD & Midbrain, thalamus, striatum & No significant difference \\
\hline Herold et al. (2006) & SERT & $\left({ }^{123}\right.$ I)ADAM & Unmedicated & Midbrain & No significant difference \\
\hline Hsieh et al. (2010) & SERT & $\left({ }^{123}\right.$ I)ADAM & Drug-free, euthymic MDD & Midbrain & No significant difference \\
\hline Parsey et al. (2006) & SERT & $\left({ }^{11} \mathrm{C}\right) \mathrm{McN} 5652$ & Drug-free MDD & AMY, Midbrain & MDD $<$ controls \\
\hline Reivich et al. (2004) & SERT & $\left({ }^{11} \mathrm{C}\right) \mathrm{McN} 5652$ & Drug-free MDD & $\begin{array}{l}\text { Left frontal cortex, right } \\
\text { cingulate cortex }\end{array}$ & MDD > controls \\
\hline Cannon et al. (2007) & SERT & $\left({ }^{11} \mathrm{C}\right) \mathrm{DASB}$ & Unmedicated & Thalamus, INS, striatum & MDD > controls \\
\hline
\end{tabular}

RN, raphe nuclei; AC, anterior cingulated cortex; AMY, amygdala; ANG, angular gyrus; DLP, dorsolateral prefrontal cortex; ITG, inferior temporal gyrus; MTG, middle temporal gyrus; STG, superior temporal gyrus; HIP, hippocampus; INS, insular cortex; MFC, medial prefrontal cortex; ORB, orbitofrontal cortex; PC, posterior cingulated cortex; SG, supramarginal gyrus; VLP, ventrolateral prefrontal cortex; VPFC, ventral prefrontal cortex; MPFC, medial PFC; DLPFC, dorsolateral PFC; CIN, cingulate cortex; PHG, parahippocampal gyrus; TEM, temporal cortex; PAR, parietal cortex; OCC, occipital cortex. 
potential in the amygdala of drug-naïve patients with MDD, ${ }^{19)}$ and increased SERT availability in the left frontal cortex and right cingulate cortex among drug-free patients. ${ }^{20)}$ Greater SERT availability was reportedly associated with more negative and dysfunctional attitudes among patients with MDD, ${ }^{21)}$ and an increase in SERT availability in the thalamus and striatum of patients with MDD was also found in a $\left[{ }^{11} \mathrm{C}\right] \mathrm{DASB}$ study. ${ }^{22)}$ These findings are shown in Table 2. As serotonergic antidepressants are an important treatment for MDD, PET is also used to probe SSRI occupancy. SERT occupancy is approximately $80 \%$ under the effective doses in PET studies using $\left[{ }^{11} \mathrm{C}\right] \mathrm{DASB}{ }^{23,24)}$

\section{Other Mood Disorders}

Altered serotonergic activity is associated with various other mood disorders. For example, increased SERT binding potential was found among unmedicated subjects with bipolar disorder in a PET study using $\left[{ }^{11} \mathrm{C}\right] \mathrm{DASB},{ }^{25)}$ and similar findings were also reported in another PET study focused on 5-HT ${ }_{1 \mathrm{~A}}{ }^{26)}$ However, a decreased level of SERT availability, as assessed by SPECT with $\left[{ }^{123} \mathrm{I}\right]$ ADAM, was found in medicated subjects with euthymic bipolar I, but not bipolar II. ${ }^{27)}$ We speculate that these findings indicate that SERT availability might not only be a biomarker for bipolar disorder but is also influenced by medication or disease severity. In addition, the biological characteristics of bipolar I and II are different. ${ }^{27)}$ It is also worth noting that altered serotonin activity may be related to the severity of symptoms associated with bipolar disorder. ${ }^{25)}$ We speculate that the mechanism between abnormal serotonegic activity and bipolar disorder may be complex.

\section{Anxiety Disorders}

Studies also indicate that serotonergic activity may be associated with anxiety disorders, ${ }^{28)}$ although the evidence remains inconclusive, with some studies reporting that there is no association, ${ }^{29)}$ or only an unclear one. ${ }^{30,31)}$ Meanwhile, reduced SERT ${ }^{32)}$ and $5-\mathrm{HT}_{2 \mathrm{~A}}{ }^{33)}$ binding potential was found among drug-naïve subjects with obsessive-compulsive disorder. Kent et al. ${ }^{34)}$ reported that occupancy of SERT by paroxetine (a kind of SSRI) was higher in patients with social anxiety disorder. Additionally, other authors found significantly lower $5-\mathrm{HT}_{1 \mathrm{~A}}$ binding potential in several limbic and paralimbic areas. ${ }^{30}$ Our preliminary small sample study of patients with generalized anxiety disorder showed no significant difference with regard to SERT level compared with a control group
(Yang et al., personal communication).

\section{Schizophrenia}

Although it has been proposed that the serotonergic system may interact with the dopaminergic system in ways that may be associated with schizophrenia, ${ }^{35,36)}$ there remains little neuroimaging evidence regarding this issue. There is reportedly no significant decrease in 5-HT receptors or SERT among schizophrenic subjects, based on PET studies using different radiotracers, ${ }^{37-40)}$ and similar findings were also reported in a SPECT study using $\left[{ }^{123} \mathrm{I}\right]$ $\beta$-CIT. ${ }^{41)}$ The role of the serotonergic system in the treatment of schizophrenia should be explored further.

\section{Addiction}

Although it has been proposed that serotonergic dysfunction may be associated with addictive behaviors, ${ }^{42,43)}$ there is little evidence from neuroimaging studies, and what exists remains inconclusive. Significantly reduced SERT availability in the brainstems of alcoholics was found with SPECT using $\left[{ }^{123} \mathrm{I}\right] \beta-\mathrm{CIT}^{44)}$ However, another study using the same radiotracer indicated that brainstem SERT availability among smokers was higher than among non-smokers. ${ }^{45)}$ Alcoholic nonsmokers reportedly had higher levels of SERT availability in the brainstem and diencephalon than controls. ${ }^{46)}$

The serotonergic system might also be also associated with other harmful forms of addiction, although the detailed mechanisms remain to be elucidated. For example, the association between serotonin and heroin use is unclear, although a SPECT study with $\left[{ }^{123} \mathrm{I}\right] \beta$-CIT indicated that the level of SERT availability was similar between heroin users and healthy controls. ${ }^{47)}$ One of our studies ${ }^{48)}$ indicated that midbrain SERT availability among opioiddependent patients being treated with low doses of methadone could be lower than that among controls and among former opioid addicts practicing methadone-free abstinence (Fig. 1). On the other hand, another study from our lab indicated that a higher level of SERT availability was associated with a greater likelihood of relapse among former heroin users. ${ }^{49)}$ We speculate, therefore, that serotonin may play a number of roles in heroin addiction. For example, both biological (e.g., homeostasis of neuroactivity) and psychological factors (e.g., depressive tendency, personality traits and risk preference) might have joint effects. Altered serotonergic activity may be associated with use of other substances, such as cocaine. An animal study indicated that acute cocaine self-administration may induce higher levels of SERT availability. ${ }^{50)}$ 


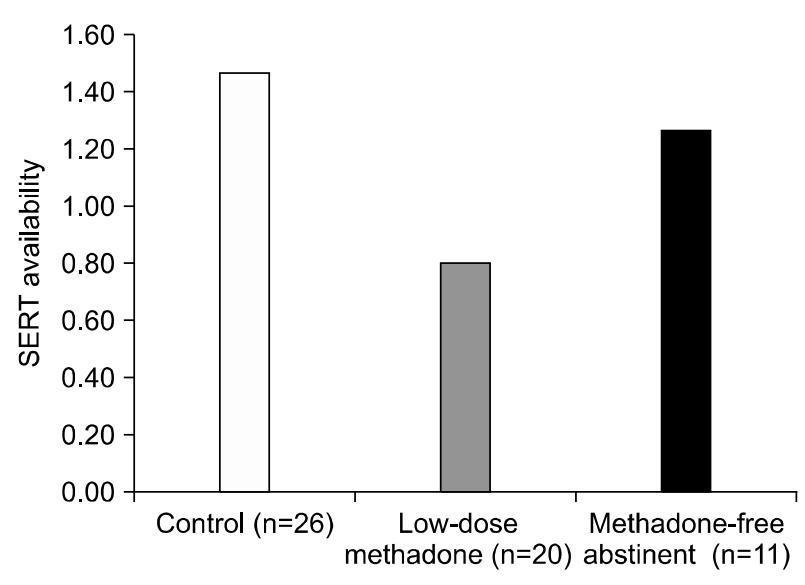

Fig. 1. The serotonin transporter (SERT) availability for heroin users and controls. Reproduced based on Yeh et $a l^{48)}$

Evidence in humans is scarce. A SPECT study found elevated SERT availability in acutely abstinent patients with cocaine dependency. ${ }^{51)}$ The association between serotonin and addiction remains to be elucidated.

\section{Attention Deficit Hyperactivity Disorder (ADHD)}

It was proposed that serotonin may play a role in ADHD via its interplay with the dopaminergic system. ${ }^{52)}$ Additionally, there was reportedly no difference in SERT availability between treatment-naïve ADHD adults and their controls, while there was a lower level of DAT among ADHD subjects. ${ }^{53)}$ Similar findings were reported in a recent small sample PET study using $\left[{ }^{11} \mathrm{C}\right]$ MADAM, which indicated that the level of SERT availability was similar between adult patients with ADHD and controls. ${ }^{54)}$

\section{Autism}

While the mechanisms of autism remain unclear, a lower level of $5-\mathrm{HT}_{2 \mathrm{~A}}$ receptor binding was found among adult men with Asperger's syndrome in a small sample SPECT study. ${ }^{55)}$ In a SPECT study using $\left[{ }^{123}\right.$ I] nor $\beta$-CIT, a significantly lower level of SERT availability in the medial frontal cortex was found among children with autism. ${ }^{56)}$ More importantly, a PET study reported lower SERT levels throughout the brain in autistic men; reduced SERT level in the anterior/posterior cingulate cortex was associated with poor social cognition. ${ }^{57)}$ Although there are few findings on autism in the literature, published work does shed some light on the etiology of this condition.

\section{Other Risks Associated with Mental Problems}

Neuroticism is a trait that may be associated with mood disorders. A PET study reported that a higher SERT binding potential was associated with neuroticism among healthy males. ${ }^{58)}$ A higher level of frontolimbic 5- $\mathrm{HT}_{2 \mathrm{~A}}$ receptor binding was reportedly associated with neuroticism among subjects with a family history of mood disorders. ${ }^{59)}$ However, little is known about the association between serotonin and other personality traits, although a lower SERT level was found among subjects with borderline personality disorder. ${ }^{60}$

The studies mentioned above suggest that a lower level of serotonergic activity might be associated with poor social interaction. ${ }^{56,57)}$ Similarly, our recent study indicated that lower SERT availability was associated with a lower level of perceived social support, ${ }^{61)}$ which is linked with stress-induced mental illness. In support of this, another of our studies also indicated that perceived stress was associated with SERT availability. ${ }^{62)}$ Furthermore, hypothalamic-pituitary-adrenal (HPA) axis function, as measured by dexamethasone suppression test, was found to be associated with SERT availability in healthy subjects. ${ }^{63)}$

\section{CONCLUSIONS}

Serotonin is one of the most important neurotransmitters and, thus, is a potential target for pharmacological treatment. A large body of evidence supports the association between the serotonergic system with MDD and other mood disorders. However, while pharmacological data support the view that serotonin could be related to anxiety disorders, imaging findings remain insufficient and inconclusive. Moreover, the association between serotonin and schizophrenia, which is the most severe psychiatric disorder, has also not been demonstrated by neuroimaging studies. The association between addiction and the serotonergic system could be complex, as the direction of its effects remains unclear. At present, little evidence supports a link between serotonin and ADHD. However, a few studies suggest that altered hyposerotonergic activity might be one of the etiologies of autism. Even in healthy participants, correlations between SERT and stressful life events and stress hormones still exist, and these findings could have implications for clinical practice.

\section{Acknowledgments}

This study was financially supported by the National Science Council of Taiwan (NSC 95-2314-B-006-115MY2, NSC 97-2314-B-006-006-MY3, NSC 100-2314B-006-041-MY3), the Atomic Energy Council of Taiwan (INER 962014L, INER 970930L, INER NL81376), and 
National Cheng Kung University Hospital (NCKUH9903019, NCKUH-10104019). This research also received funding from the Headquarters of University Advancement at the National Cheng Kung University, which is sponsored by the Ministry of Education, Taiwan, ROC. The funding institutions had no further role in the study design, the collection, analysis, and interpretation of data, the writing of this paper, or the decision to submit it for publication. The authors report no financial relationships with commercial interests.

\section{REFERENCES}

1. Stanley M, Mann JJ. Increased serotonin-2 binding sites in frontal cortex of suicide victims. Lancet 1983;1:214-216.

2. Berger M, Gray JA, Roth BL. The expanded biology of serotonin. Annu Rev Med 2009;60:355-366.

3. Paterson LM, Kornum BR, Nutt DJ, Pike VW, Knudsen GM. 5-HT radioligands for human brain imaging with PET and SPECT. Med Res Rev 2013;33:54-111.

4. Zipursky RB, Meyer JH, Verhoeff NP. PET and SPECT imaging in psychiatric disorders. Can $J$ Psychiatry 2007:52:146-157.

5. Nikolaus S, Hautzel H, Heinzel A, Müller HW. Key players in major and bipolar depression--a retrospective analysis of in vivo imaging studies. Behav Brain Res 2012;232:358390.

6. Drevets WC, Frank E, Price JC, Kupfer DJ, Holt D, Greer $\mathrm{PJ}$, et al. PET imaging of serotonin $1 \mathrm{~A}$ receptor binding in depression. Biol Psychiatry 1999;46:1375-1387.

7. Sargent PA, Kjaer KH, Bench CJ, Rabiner EA, Messa C, Meyer J, et al. Brain serotonin1A receptor binding measured by positron emission tomography with $\left[{ }^{11} \mathrm{C}\right] W A Y-$ 100635: effects of depression and antidepressant treatment. Arch Gen Psychiatry 2000;57:174-180.

8. Hirvonen J, Karlsson H, Kajander J, Lepola A, Markkula $\mathrm{J}$, Rasi-Hakala $\mathrm{H}$, et al. Decreased brain serotonin 5-HT1A receptor availability in medication-naive patients with major depressive disorder: an in-vivo imaging study using $P E T$ and [carbonyl-11C]WAY-100635. Int J Neuropsychopharmacol 2008;11:465-476.

9. Bhagwagar Z, Rabiner EA, Sargent PA, Grasby PM, Cowen PJ. Persistent reduction in brain serotonin1A receptor binding in recovered depressed men measured by positron emission tomography with $\left[{ }^{11} \mathrm{C}\right] W A Y-100635$. Mol Psychiatry 2004;9:386-392.

10. Parsey RV, Oquendo MA, Ogden RT, Olvet DM, Simpson $\mathrm{N}$, Huang YY, et al. Altered serotonin $1 A$ binding in major depression: a [carbonyl-C-11]WAY100635 positron emission tomography study. Biol Psychiatry 2006;59:106-113.

11. Malison RT, Price LH, Berman R, van Dyck CH, Pelton $\mathrm{GH}$, Carpenter L, et al. Reduced brain serotonin transporter availability in major depression as measured by $\left[{ }^{123} I\right]-2$ beta-carbomethoxy-3 beta-(4-iodophenyl)tropane and single photon emission computed tomography. Biol Psychiatry 1998;44:1090-1098.

12. Newberg AB, Amsterdam JD, Wintering N, Ploessl $\mathrm{K}$, Swanson RL, Shults J, et al. ${ }^{123}$ I-ADAM binding to serotonin transporters in patients with major depression and healthy controls: a preliminary study. J Nucl Med 2005;46:973-977.

13. Joensuu M, Tolmunen T, Saarinen PI, Tiihonen J, Kuikka $\mathrm{J}$, Ahola $\mathrm{P}$, et al. Reduced midbrain serotonin transporter availability in drug-naïve patients with depression measured by SERT-specific [(123)I] nor-beta-CIT SPECT imaging. Psychiatry Res 2007;154:125-131.

14. Ahonen A, Heikman P, Kauppinen T, Koskela A, Bergstrom K. Serotonin transporter availability in drug free depression patients using a novel SERT ligand. Eur J Nucl Med Mol Imaging 2004;31:S227-S228

15. Catafau AM, Perez V, Plaza P, Pascual JC, Bullich S, Suarez M, et al. Serotonin transporter occupancy induced by paroxetine in patients with major depression disorder: a ${ }^{123}$ I-ADAM SPECT study. Psychopharmacology (Berl) 2006; 189:145-153.

16. Herold N, Uebelhack K, Franke L, Amthauer H, Luedemann $\mathrm{L}$, Bruhn $\mathrm{H}$, et al. Imaging of serotonin transporters and its blockade by citalopram in patients with major depression using a novel SPECT ligand [123I]-ADAM. J Neural Transm 2006;113:659-670.

17. Hsieh PC, Lee IH, Yeh TL, Chen KC, Huang HC, Chen PS, et al. Distribution volume ratio of serotonin and dopamine transporters in euthymic patients with a history of major depression - a dual-isotope SPECT study. Psychiatry Res 2010;184:157-161.

18. Hsieh PC, Chen KC, Yeh TL, Lee IH, Chen PS, Yao WJ, et al. Lower availability of midbrain serotonin transporter between healthy subjects with and without a family history of major depressive disorder - a preliminary two-ligand SPECT study. Eur Psychiatry 2014. pii: S0924-9338(13) 00445-8. [Epub ahead of print]

19. Parsey RV, Hastings RS, Oquendo MA, Huang YY, Simpson N, Arcement J, et al. Lower serotonin transporter binding potential in the human brain during major depressive episodes. Am J Psychiatry 2006;163:52-58.

20. Reivich M, Amsterdam JD, Brunswick DJ, Shiue CY. PET brain imaging with $\left[{ }^{11} \mathrm{C}\right](+) M c N 5652$ shows increased serotonin transporter availability in major depression. $J$ Affect Disord 2004;82:321-327.

21. Meyer JH, Houle S, Sagrati S, Carella A, Hussey DF, Ginovart $\mathrm{N}$, et al. Brain serotonin transporter binding potential measured with carbon 11-labeled DASB positron emission tomography: effects of major depressive episodes and severity of dysfunctional attitudes. Arch Gen Psychiatry 2004;61:1271-1279.

22. Cannon DM, Ichise M, Rollis D, Klaver JM, Gandhi SK, Charney DS, et al. Elevated serotonin transporter binding in major depressive disorder assessed using positron emission tomography and $\left[{ }^{11} C\right] D A S B$; comparison with bipolar disorder. Biol Psychiatry 2007;62:870-877.

23. Meyer JH. Imaging the serotonin transporter during major depressive disorder and antidepressant treatment. J Psychiatry Neurosci 2007:32:86-102.

24. Meyer JH, Wilson AA, Ginovart N, Goulding V, Hussey D, Hood $\mathrm{K}$, et al. Occupancy of serotonin transporters by paroxetine and citalopram during treatment of depression: a [(11)C]DASB PET imaging study. Am J Psychiatry 2001; 158:1843-1849.

25. Cannon DM, Ichise M, Fromm SJ, Nugent AC, Rollis D, Gandhi SK, et al. Serotonin transporter binding in bipolar disorder assessed using $\left[{ }^{11} C\right] D A S B$ and positron emission tomography. Biol Psychiatry 2006;60:207-217.

26. Sullivan GM, Ogden RT, Oquendo MA, Kumar JS, Simpson $\mathrm{N}$, Huang YY, et al. Positron emission tomography quantification of serotonin-1A receptor binding in medicationfree bipolar depression. Biol Psychiatry 2009;66:223-230.

27. Chou YH, Wang SJ, Lin CL, Mao WC, Lee SM, Liao MH. Decreased brain serotonin transporter binding in the 
euthymic state of bipolar I but not bipolar II disorder: a SPECT study. Bipolar Disord 2010;12:312-318.

28. Freitas-Ferrari MC, Hallak JE, Trzesniak C, Filho AS, Machado-de-Sousa JP, Chagas MH, et al. Neuroimaging in social anxiety disorder: a systematic review of the literature. Prog Neuropsychopharmacol Biol Psychiatry 2010;34:565580.

29. Maron E, Kuikka JT, Ulst K, Tiihonen J, Vasar V, Shlik J. SPECT imaging of serotonin transporter binding in patients with generalized anxiety disorder. Eur Arch Psychiatry Clin Neurosci 2004;254:392-396.

30. Lanzenberger RR, Mitterhauser M, Spindelegger C, Wadsak $\mathrm{W}$, Klein N, Mien LK, et al. Reduced serotonin-1A receptor binding in social anxiety disorder. Biol Psychiatry 2007; 61:1081-1089.

31. van der Wee NJ, van Veen JF, Stevens H, van Vliet IM, van Rijk PP, Westenberg HG. Increased serotonin and dopamine transporter binding in psychotropic medicationnaive patients with generalized social anxiety disorder shown by ${ }^{123}$ I-beta-(4-iodophenyl)-tropane SPECT. J Nucl Med 2008;49:757-763.

32. Hesse S, Müller U, Lincke T, Barthel H, Villmann T, Angermeyer MC, et al. Serotonin and dopamine transporter imaging in patients with obsessive-compulsive disorder. Psychiatry Res 2005;140:63-72.

33. Perani D, Garibotto V, Gorini A, Moresco RM, Henin M, Panzacchi A, et al. In vivo PET study of $5 H T(2 A)$ serotonin and $D(2)$ dopamine dysfunction in drug-naive obsessivecompulsive disorder. Neuroimage 2008;42:306-314.

34. Kent JM, Coplan JD, Lombardo I, Hwang DR, Huang Y, Mawlawi $\mathrm{O}$, et al. Occupancy of brain serotonin transporters during treatment with paroxetine in patients with social phobia: a positron emission tomography study with ${ }^{11}$ C McN 5652. Psychopharmacology (Berl) 2002;164:341348.

35. Iqbal N, van Praag HM. The role of serotonin in schizophrenia. Eur Neuropsychopharmacol 1995;5 Suppl:11-23.

36. Kapur S, Remington G. Serotonin-dopamine interaction and its relevance to schizophrenia. Am J Psychiatry 1996;153: 466-476.

37. Trichard C, Paillère-Martinot ML, Attar-Levy D, Blin J, Feline A, Martinot JL. No serotonin 5-HT2A receptor density abnormality in the cortex of schizophrenic patients studied with PET. Schizophr Res 1998;31:13-17.

38. Lewis R, Kapur S, Jones C, DaSilva J, Brown GM, Wilson $\mathrm{AA}$, et al. Serotonin 5-HT2 receptors in schizophrenia: a PET study using ${ }^{18} \mathrm{~F} /$ setoperone in neuroleptic-naive patients and normal subjects. Am J Psychiatry 1999; 156:72-78.

39. Frankle WG, Lombardo I, Kegeles LS, Slifstein M, Martin $\mathrm{JH}$, Huang Y, et al. Serotonin $1 A$ receptor availability in patients with schizophrenia and schizo-affective disorder: a positron emission tomography imaging study with $\left.{ }^{11} C\right] W A Y$ 100635. Psychopharmacology (Berl) 2006;189:155-164.

40. Frankle WG, Narendran R, Huang Y, Hwang DR, Lombardo I, Cangiano C, et al. Serotonin transporter availability in patients with schizophrenia: a positron emission tomography imaging study with $\left[{ }^{11} C\right] D A S B$. Biol Psychiatry 2005; $57: 1510-1516$.

41. Laruelle M, Abi-Dargham A, van Dyck C, Gil R, D'Souza DC, Krystal J, et al. Dopamine and serotonin transporters in patients with schizophrenia: an imaging study with [(123)I]beta-CIT. Biol Psychiatry 2000;47:371-379.

42. Schmidt LG, Dufeu P, Heinz A, Kuhn S, Rommelspacher H. Serotonergic dysfunction in addiction: effects of alcohol, cigarette smoking and heroin on platelet 5-HT content. Psychiatry Res 1997;72:177-185.

43. Volkow ND, Fowler JS. Addiction, a disease of compulsion and drive: involvement of the orbitofrontal cortex. Cereb Cortex 2000;10:318-325.

44. Heinz A, Ragan P, Jones DW, Hommer D, Williams W, Knable $\mathrm{MB}$, et al. Reduced central serotonin transporters in alcoholism. Am J Psychiatry 1998;155:1544-1549.

45. Staley JK, Krishnan-Sarin S, Zoghbi S, Tamagnan G, Fujita $\mathrm{M}$, Seibyl JP, et al. Sex differences in [123I]beta-CIT SPECT measures of dopamine and serotonin transporter availability in healthy smokers and nonsmokers. Synapse 2001; $41: 275-284$

46. Cosgrove KP, Krantzler E, Frohlich EB, Stiklus S, Pittman $\mathrm{B}$, Tamagnan GD, et al. Dopamine and serotonin transporter availability during acute alcohol withdrawal: effects of comorbid tobacco smoking. Neuropsychopharmacology 2009;34:2218-2226.

47. Cosgrove KP, Tellez-Jacques K, Pittman B, Petrakis I, Baldwin RM, Tamagnan G, et al. Dopamine and serotonin transporter availability in chronic heroin users: a $\left[{ }^{123} \mathrm{I}\right] \beta$ -CIT SPECT imaging study. Psychiatry Res 2010;184: 192-195.

48. Yeh TL, Chen KC, Lin SH, Lee IH, Chen PS, Yao WJ, et al. Availability of dopamine and serotonin transporters in opioid-dependent users--a two-isotope SPECT study. Psychopharmacology (Berl) 2012;220:55-64.

49. Lin SH, Chen KC, Lee SY, Yao WJ, Chiu NT, Lee IH, et al. The association between availability of serotonin transporters and time to relapse in heroin users: a two-isotope SPECT small sample pilot study. Eur Neuropsychopharmacol 2012;22:647-650.

50. Banks ML, Czoty PW, Gage HD, Bounds MC, Garg PK, Garg S, et al. Effects of cocaine and MDMA selfadministration on serotonin transporter availability in monkeys. Neuropsychopharmacology 2008;33:219-225.

51. Jacobsen LK, Staley JK, Malison RT, Zoghbi SS, Seibyl JP, Kosten TR, et al. Elevated central serotonin transporter binding availability in acutely abstinent cocaine-dependent patients. Am J Psychiatry 2000;157:1134-1140.

52. Oades RD. Dopamine-serotonin interactions in attentiondeficit hyperactivity disorder (ADHD). Prog Brain Res 2008; 172:543-565.

53. Hesse S, Ballaschke O, Barthel H, Sabri O. Dopamine transporter imaging in adult patients with attention-deficit/ hyperactivity disorder. Psychiatry Res 2009;171:120-128.

54. Karlsson L, Tuominen L, Huotarinen A, Leppämäki S, Sihvola E, Helin S, et al. Serotonin transporter in attention-deficit hyperactivity disorder--preliminary results from a positron emission tomography study. Psychiatry Res 2013;212:164-165.

55. Murphy DG, Daly E, Schmitz N, Toal F, Murphy K, Curran $\mathrm{S}$, et al. Cortical serotonin 5-HT2A receptor binding and social communication in adults with Asperger's syndrome: an in vivo SPECT study. Am J Psychiatry 2006;163:934936.

56. Makkonen I, Riikonen R, Kokki H, Airaksinen MM, Kuikka JT. Serotonin and dopamine transporter binding in children with autism determined by SPECT. Dev Med Child Neurol 2008;50:593-597.

57. Nakamura K, Sekine Y, Ouchi Y, Tsujii M, Yoshikawa E, Futatsubashi $\mathrm{M}$, et al. Brain serotonin and dopamine transporter bindings in adults with high-functioning autism. Arch Gen Psychiatry 2010;67:59-68.

58. Takano A, Arakawa R, Hayashi M, Takahashi H, Ito H, 
Suhara T. Relationship between neuroticism personality trait and serotonin transporter binding. Biol Psychiatry 2007; 62:588-592.

59. Frokjaer VG, Vinberg M, Erritzoe D, Baaré W, Holst KK, Mortensen EL, et al. Familial risk for mood disorder and the personality risk factor, neuroticism, interact in their association with frontolimbic serotonin $2 A$ receptor binding. Neuropsychopharmacology 2010;35:1129-1137.

60. Koch W, Schaaff N, Pöpperl G, Mulert C, Juckel G, Reicherzer $\mathrm{M}$, et al. [I-123] ADAM and SPECT in patients with borderline personality disorder and healthy control subjects. J Psychiatry Neurosci 2007;32:234-240.

61. Huang HY, Lee IH, Chen KC, Lin SH, Yeh TL, Chen PS, et al. Serotonin transporter availability in the midbrain and perceived social support in healthy volunteers. J Psychosom Res 2013;75:577-581.

62. Yeh TL, Lee IH, Chen KC, Chen PS, Yao WJ, Yang YK, et al. The relationships between daily life events and the availabilities of serotonin transporters and dopamine transporters in healthy volunteers--a dual-isotope SPECT study. Neuroimage 2009;45:275-279.

63. Tsai HY, Lee IH, Yeh TL, Yao WJ, Chen KC, Chen PS, et al. Association between the dexamethasone suppression test and serotonin transporter availability in healthy volunteer: a SPECT with [(123)I] ADAM study. Eur Neuropsychopharmacol 2012;22:641-646. 